\title{
Infrapatellar bursitis presenting as a lump
}

\author{
Mantu Jain 도 , Manmatha Nayak, Sajid Ansari, Bishnu Prasad Patro
}

Orthopaedics, All India Institute of Medical Sciences, Bhubaneswar, India

\section{Correspondence to Dr Mantu Jain;} montu_jn@yahoo.com

Accepted 12 May 2021

\section{DESCRIPTION}

A bursa is a fluid-filled sac meant to reduce the friction between surfaces. ${ }^{1}$ A bursa can be superficial when present between the skin and underlying tendon or bone such as the prepatellar, infrapatellar, olecranon bursa or superficial calcaneal. ${ }^{2}$ Deep bursae are located deep to the facia, typically between muscles, tendon, and bones. ${ }^{3} 4$ Trauma, particularly repetitive, overuse, haemorrhage and, crystal disease, infection, are some of the common causes for inflammation of the bursa leading to bursitis. ${ }^{1356}$ There could be systemic illness in some cases, and in a few, the cause remains unknown. ${ }^{7}$ Occupation and habitual or practices predispose certain types known by eponyms such as prepatellar bursitis, also known as housemaid's knee, and superficial infrapatellar bursitis synonymous with clergyman's knee. ${ }^{8}$ The bursa with chronic inflammation may have calcification or become a solid lump losing its fluid content. ${ }^{79}$ This case depicts such a case wherein the patient presented with painful swelling.

A 58-year-aged man, clerical by job, presented to our outpatient department with painful swelling (Visual Analogue Score of 4/10) over the anterior aspect of the right knee just inferior to the patella for almost a year (figure 1A). He had a history of minor trauma to the knee. On examination, the lump was solitary, slightly tender and roughly measured $5 \times 5 \mathrm{~cm}$ with slight discoloration of the overlying skin. Extremes knee flexion and extension aggravated the pain. The blood investigations, including a complete blood count, acute phase reactants, were within the normal limit. The serum uric acid and autoimmune markers such as the antinuclear antibody, rheumatoid factor, and the anti-citric citrullinated peptide were also unremarkable. Radiological investigations included an X-ray of the knees where the soft tissue swelling could be appreciated without any calcification or ossification (figure 1B). A MRI revealed a well-defined, subcutaneous, elliptical mass in the midline, which was superficial to the tibial tuberosity. The mass was hypointense on T1-weighted but hyperintense on T2-weighted and
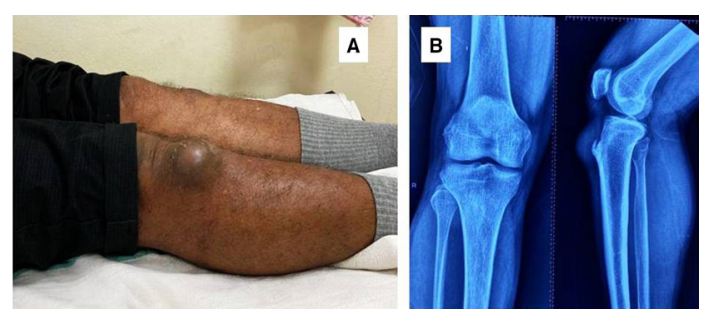

Figure 1 Clinical picture of patient showing the lump (A). (B) The x-ray revealing the soft-tissue swelling without calcification/ ossification.
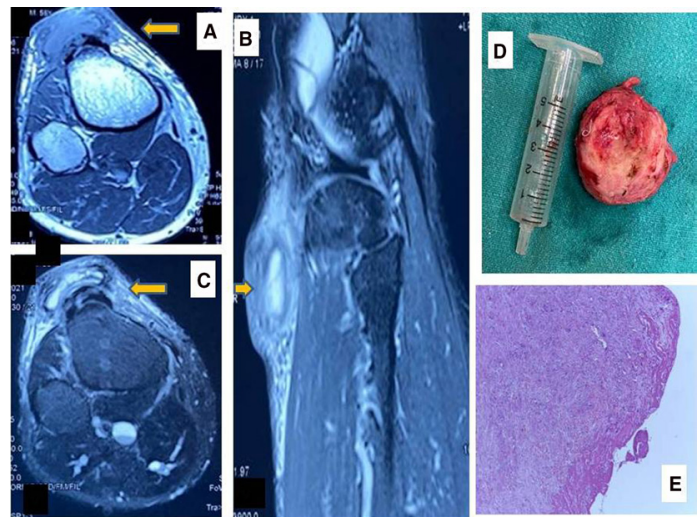

Figure 2 MRI findings axial and sagittal showing fluid filled sac (A-C); excised mass (D) and histopathological study displaying chronic inflammatory tissue covered with fibrinous debris; 20x; H\&E stain (E).

fat-suppressed images associated with surrounding subcutaneous oedema (figure $2 \mathrm{~A}-\mathrm{C}$ ). The patient was counselled for an excisional biopsy. Under local anaesthesia, a midline incision was made and the mass was removed in toto and sent for histopathological examination (figure 2D). The macroscopic examination revealed a soft to firm yellowish mass without any haemorrhage, necrosis or gritty sensation on cutting. Microscopic examination revealed chronic inflammation tissue covered with fibrinous debris (figure 2E).

Infrapatellar bursitis can be a source of anterior knee pain. ${ }^{10} 11$ Common mechanism is repetitive injury from prolonged kneelings such as a cleaner or clergyman. Some people give a relation of trauma as in our case in the absence of habitual practice. Most remain painless, yet situations with extremes of movement like squatting, which is standard practice in rural Indian set-up, may cause stimulation of nociceptive mechanoreceptors leading to pain as reported by our patient. Pain can also arise due to infection or inflammatory disease of deep infrapatellar bursa (DIPB). ${ }^{11}$ Taylor found gout affecting DIPB ${ }^{12}$ while Klein has reported DIPB secondary to Osgood Schatter disease. ${ }^{13}$ Inflammation of DIPB will produce localised tenderness and thickening of the soft tissues posterior medial and lateral to the patellar tendon. Continued mechanical irritation of an inflamed bursa could lead to fibrosis and calcification. ${ }^{14}$ Ultrasonography can be handy for detecting soft-tissue changes and bursitis in the carpet layer. ${ }^{15}$ Aspiration of a bursa and subjecting to microbiological gram staining is a must in suspicion of infective pathology. The role of fine-needle aspiration and cytology is doubtful. Arora et al found negative in two attempts. ${ }^{9}$ 
The differential diagnosis includes infective and tumorous conditions such as tenosynovitis giant cell, tumour, fibromatosis, haemangioma, or malignant conditions like synovial sarcomas, especially in the presence of speckled calcification. ${ }^{914}$

The treatment in acute cases includes rest, ice compression, and elevation (RICE therapy) with medications like nonsteroidal anti-inflammatory drugs. In large non-infectious swellings, the bursa can be aspirated, and intrabursal steroid injections could be used. Infectious bursitis require antibiotics and in some instances could require surgical drainage as well. ${ }^{16}$ Chronic bursitis is usually painless and can be treated with observation if not interfering with activities of daily living. However, patinets with cosmetic concern, acute excerbation of pain or secondary infection would rerquire a removal of bursa. The infrapetallar bursa if supercial like our case is easily accesible for surgical excsion. But, for DIPB, recently, an endoscopic resection has been described. ${ }^{11}$

Infrapatellar bursitis is more common in repetitive knee trauma, but sometimes aetiology remains elusive. At the same time, awareness of the lesions helps arrive at the correct diagnosis, which, in turn, helps in proper management.

\section{Learning points}

Different types of bursa are seen around the knee joint.

- Chronic bursitis is painless and can be observed but when symptomatic or complicated requires surgical excision.

- Chronic bursitis can present as lump which must be further investigated.

Acknowledgements Dr. Suprava Naik for giving the MRI images. Dr. Manas Baisakh for giving the histological picture.

Contributors MJ, SA, and MN operated on the patient. BPP did a literature review. SA followed up with the patient. MJ and MN wrote the paper where SA, BPP gave valuable inputs.
Funding The authors have not declared a specific grant for this research from any funding agency in the public, commercial or not-for-profit sectors.

Competing interests None declared.

Patient consent for publication Obtained.

Provenance and peer review Not commissioned; externally peer reviewed.

\section{ORCID iDs}

Mantu Jain http://orcid.org/0000-0003-3848-4277

Bishnu Prasad Patro http://orcid.org/0000-0001-9497-9624

\section{REFERENCES}

1 Chatra PS. Bursae around the knee joints. Indian J Radiol Imaging 2012;22:27-30.

2 Khodaee M. Common superficial bursitis. Am Fam Physician 2017;95:224-31.

3 Williams CH, Jamal Z, Sternard BT. Bursitis. In: StatPearls. Treasure Island FL: StatPearls Publishing, 2021.

4 Koh WL, Kwek JW, Quek ST, et al. Clinics in diagnostic imaging (77). PEs anserine bursitis. Singapore Med J 2002;43:485-91 http://www.ncbi.nlm.nih.gov/entrez/query. $\mathrm{fcgi}$ ?cmd=Retrieve \&db=PubMed\&dopt=Citation\&list_uids $=12568429$

5 Dawn B, Williams JK, Walker SE. Prepatellar bursitis: a unique presentation of tophaceous gout in an normouricemic patient. J Rheumatol 1997;24:976-8.

6 Hirji Z, Hunjun JS, Choudur HN. Imaging of the bursae. J Clin Imaging SCi 2011;1:22-2.

7 McCarthy EM, Murphy C-L, Doran MF, et al. Infrapatellar bursitis: an occupational legacy. J Clin Rheumatol 2011;17:49-50.

8 Lee P, Hunter TB, Taljanovic M. Musculoskeletal colloquialisms: how did we come up with these names? Radiographics 2004;24:1009-27.

9 Arora S, Batra S, Rao S, et al. "A 40-year-old female with painless, slow growing prepatellar mass". J Clin Orthop Trauma 2014;5:274-9.

10 Waters P, Kasser J. Infection of the infrapatellar bursa. A report of two cases. J Bone Joint Surg Am 1990;72:1095-6.

11 LaPrade RF. The anatomy of the deep infrapatellar bursa of the knee. Am J Sports Med 1998;26:129-32

12 Taylor PW. Inflammation of the deep infrapatellar bursa of the knee. Arthritis Rheum 1989;32:1312-4

13 Klein W. Endoscopy of the deep infrapatellar bursa. Arthroscopy 1996;12:127-31

14 Stahnke M, Mangham DC, Davies AM. Calcific haemorrhagic bursitis anterior to the knee mimicking a soft tissue sarcoma: report of two cases. Skeletal Radiol 2004;33:363-6.

15 Myllymäki T, Tikkakoski T, Typpö T. Carpet-layer ' S knee. An ultrasonographic study. Acta Radiol 1993:35:496-9.

16 Lormeau C, Cormier G, Sigaux J, et al. Management of septic bursitis. Joint Bone Spine 2019;86:583-8.

Copyright 2021 BMJ Publishing Group. All rights reserved. For permission to reuse any of this content visit

https://www.bmj.com/company/products-services/rights-and-licensing/permissions/

BMJ Case Report Fellows may re-use this article for personal use and teaching without any further permission.

Become a Fellow of BMJ Case Reports today and you can:

- Submit as many cases as you like

Enjoy fast sympathetic peer review and rapid publication of accepted articles

- Access all the published articles

Re-use any of the published material for personal use and teaching without further permission

Customer Service

If you have any further queries about your subscription, please contact our customer services team on +44 (0) 2071111105 or via email at support@bmj.com.

Visit casereports.bmj.com for more articles like this and to become a Fellow 